\title{
RESCUING POLITICS FROM LYING AND HYPOCRISY: UTILITY AND TRUTH IN JEREMY BENTHAM'S THOUGHT
}

\author{
RESGATANDO A POLÍTICA DA MENTIRA E HIPOCRISIA: \\ UTILIDADE E VERDADE NO PENSAMENTO DE JEREMY BENTHAM
}

Benjamin Bourcier* benjamin.bourcier@univ-catholille.fr

\begin{abstract}
As a utilitarian philosopher, Jeremy Bentham (1748-1832) devoted most of his career to create a new institutional setting to promote the greatest happiness of the greatest number on the basis of the principle of utility. In doing so, Bentham committed himself not only to the value of utility but also to truth. Truth meant universal interest and denouncing all abuses of power and corruptions that sacrifice the interest of the greatest number. As two opponents of truth, lies and hypocrisy are the symptoms of the sacrifice of the universal interest and directly oppose the principle of utility. Yet, what is at stake in this opposition? How did Bentham value and analyze these two phenomenon? In this paper, I will explain how Bentham's commitment against lying and hypocrisy in politics aims to support the truth of the utilitarian principle and demonstrates the wrongness of other moral principles.
\end{abstract}

Keywords: Hypocrisy, Lying, Asceticism, Principle of Utility, Utilitarianism, Jeremy Bentham.

Sumário. Como filósofo utilitarista, Jeremy Bentham (1748-1832) dedicou a maior parte de sua carreira à criação de um novo ambiente institucional que promovesse a maior felicidade do maior número de pessoas, com base no princípio da utilidade. Assim, Bentham comprometeu-se não só com o valor da utilidade mas também com a verdade. Verdade significava interesse universal e a denúncia de todos os abusos de poder e corrupções que sacrificavam o interesse do maior número de pessoas. A mentira e a hipocrisia, enquanto dois adversários da verdade, são os sintomas do sacrifício do interesse universal e opõem-se diretamente ao princípio da utilidade. No entanto, o que está em jogo nesta oposição? De que maneira Bentham valorizou e analisou esses dois fenómenos? Neste artigo, explicarei como o compromisso de Bentham contra a mentira e a hipocrisia na política visa apoiar a verdade do princípio utilitarista e demonstrar a injustiça de outros princípios morais.

\footnotetext{
"Associate-Professor of moral and political philosophy, ESPOL, Catholic University of Lille.
} 
Palavras-chave: Hipocrisia, Mentira, Ascetismo, Princípio da Utilidade, Utilitarismo, Jeremy Bentham.

\section{Bentham's Political Ethics: Securing the Interest of the Greatest Number, Excluding Lying.}

Bentham asserts the articulation ${ }^{1}$ between truth and the principle of utility throughout his career. While the relation between truth and utility remains highly problematic and difficult to understand completely in his philosophy (Quinn, 2012; Schofield, 2015), ${ }^{2}$ lying, as the opposite of truth, questions how Bentham's collective utilitarian thought deals with non-true statement in his effort to create impartial and just public institutions to realize the greatest happiness of the greatest number. In this debate, Bentham thought that discourses are always the mirror of individuals' interests and, if each individual is the best judge of his own interest, it is highly probable that his discourse expresses his interests and his desire to promote them. As a collective utilitarian who devoted his entire career to reform institutions, legal codes and public policies, then, the issue of lies in public discourses remains of special importance. Indeed, with this topic, Bentham engages with a specific question in his thought: could the universal interest be promoted by public institutions while public officials looked out for their own interests? How could the adequacy between public official's minds and their functions in the institutions be created and tailored on the basis of the principle of utility? As I will explain, Bentham presents a definitive answer to this issue that he strongly supports throughout his writings. He thinks that public officials' lies are the symptoms of the "sinister interests" (Schofield, 2006, Ch. 5), i.e. private interests that will sacrifice the universal interest. Hence, in order to secure the greatest happiness of the greatest number, Bentham commands the complete exclusion of lying in the ethics of politics.

\footnotetext{
${ }^{1}$ For instance : "D'abord à force de faire agir cette phrase, on s'est égaré du chemin de l'utilité ; seul guide qui mène à la vérité en faite de morale : seul dictateur légitime de nos jugemens de la bonté et de la méchanceté des actions” (Bentham, 2016, p. 389).

${ }^{2}$ In his article, Schofield (2015) argues that the relation between truth and utility are not unequivocal in the sense that the different alternatives that describe their relation might all appear in some domains of Bentham's thought (whether utility subordinate truth, truth subordinates utility and, lastly, whether both are mutually supportive). In the case of religion, Schofield argues that utility and truth are mutually supportive.
} 
In order to understand Bentham's radical commitment to exclude lying in the ethics of politics, I will proceed in two steps. Firstly, I will explain how Bentham thinks that the mind of public officials and their interests should integrate the utilitarian code until it is perfectly internalized. Bentham's ethics of politics proceeds in different stages from the selection of public officials to the development of specific aptitudes. Ultimately, all public officials should comply with the set of rules and aptitudes promoted by the utilitarian code. 3 These aptitudes will lead public officials to fulfill a duty of sincerity that demonstrates their commitment to the greatest happiness of the greatest number. Secondly, the role of the liberty of the press remains central for securing the interest of the greatest number. Bentham thinks that newspapers and public opinion, even based on bad faith and lies, are necessary expressions of conflicting interests and remains the best control of public institutions. Bentham tolerates lies made against public officials and rejects all limitations of the liberty of the press and liberty of speech in general. Newspapers and the public have the power to control the rulers and this power should not be bounded.

\subsection{Securing the Perfect Internalization of the Utilitarian Code.}

Bentham's ethics of politics is mainly developed under the name of "public deontology."

By Deontology, taken in its largest sense, is meant that branch of art and science which has for its object the doing on each occasion what is right and proper to be done. In its ordinary acceptation however, the use of it was confined to that part of the field of thought and action which is considered as forming the subject matter of Government and Morality. For distinction sake, in so far as it takes for its subject matter that part of the field to which Government applies itself, Public Deontology is the name that may be employed: in so far as the application of it is considered as confined to those parts of the field of thought and action which Government has left free, Private Deontology is the name that may be employed (Bentham, 1983a, p. 249).

"Public deontology" constitutes the largest part of the field of ethics in Bentham's thought. With this concept, Bentham aims to explain how just and impartial public institutions require that each and every public official's interest supports the general utilitarian maxim, the greatest happiness of the greatest

\footnotetext{
${ }^{3}$ The problem of compliance to the set of rules that shape public institutions is largely characterized as authoritarian in Bentham's public philosophy.
} 
number. Just and impartial public institutions rely ultimately on the ability of public officials to act, think and make decisions that are guided by the principle of utility. Bentham's "public deontology" is mostly described and theorized in Bentham's writings (Bentham, 1989a; 1989b; 1993; 1995; 2002) on constitutional law, institutional design, arrangements, publicity and transparency.

Bentham's ethics of politics relies on a system of control and motivation devoted to create the artificial junction (Harrison, 1983, Ch. 5) between the interest and the duty of the functionary. The utilitarian ethics of politics is built on the idea that a system of motivation and control based on reward would be counterproductive since it would not find an objective measure between the reward awarded and the benefit obtained by the official and the good government. Instead of the promise of a gain and more generally of a positive utility, a system of control and motivation made of rules, arrangements, publicity and based on clear definitions of sanctions would influence the conduct of the public official in a more effective way so that he will be encouraged to act adequately with the utilitarian code. I would like to add that this argument is largely consistent with Bentham's anthropology which considers that the value of pain is always greater than that of pleasure from the motivational point of view and thus offers, from the epistemological point of view, a more reliable prospective objectification of states of things that respond to the principle of utility. As such, a utilitarian ethics of politics based on a system of control of motivation is then the best approach for achieving the greatest happiness of the greatest number.

\subsection{Selection of Public Functionaries.}

That said, a utilitarian ethics of politics inspired by this general idea aims firstly to find the appropriate candidates for public office and needs then to proceed to the selection of functionaries in conformity with this system of motivation and control. The selection of public functionaries is guided by a maxim that Bentham quotes in many texts: "Official Aptitude Maximized; Expense Minimized" (Bentham, 1993). The application of this maxim is described in its complete form in Bentham's masterpiece Constitutional Code. In Chapter 6 , Bentham details how the conditions of remuneration of members of the 
National Assembly are articulated in acts of presence where an "entry procedure" and an "attendance code" are fixed. The control of the presence of the Deputees leads to calculate the number of days of work corresponding and help to calculate their salary. The system of remuneration is also defined by the principle of "minimization" (Bentham, 1989a, pp. 297-310) which implies that the selection of the best candidate requires that they compete for the lower remuneration. These elements demonstrate how the system of motivation and control is a procedural, authoritarian and competitive method that describes the different stages through which a candidate has to undergo until he is hired by the State for a particular office. But the selection of candidates is not the only subject. The utilitarian code aims more generally towards the transformation of the interests of the public official in such a way that his interests will no longer be partial and personal but will suit perfectly with the duty that the principle of utility commands. Bentham's ethics of politics is centrally based on the idea of the artificial identification of one public official's duty towards his interests. This artificial identification of the duty and the interest is narrowly related to the concept of "aptitudes". This concept explains how one public official internalizes the utilitarian code designed according to his office. After the selection and the long procedure of evaluation of the candidates, the new public official is trained and educated to incorporate the utilitarian code composed of moral and legal prescriptions. With this code, the "universal interest" is secured and, the public official also knows which sanctions will apply if his actions follow his own private interests and despise or misunderstand his duty.

\subsection{The Doctrine of Aptitudes.}

In order to secure the impartiality of public institutions, Bentham develops the idea that good functionaries have to internalize different "aptitudes". The doctrine of aptitudes explains how the incorporation of the utilitarian code is realized. Bentham defines the "aptitude" as the "quality of constitutional arrangements" (Schofield, 1996) and not as an individual ethos. It is the capacity and disposition created by these arrangements for an individual to internalize the utilitarian code. Bentham distinguishes three different "aptitudes".

Appropriate aptitude is aptitude with relation to the end. In the case of a functionary of Government, appropriate aptitude is appropriate official aptitude. Of appropriate aptitude with relation to the end of government and laws, three branches or elements 
require to be distinguished, namely, 1. Appropriate moral aptitude: 2. Appropriate intellectual aptitude: 3. Appropriate active aptitude (Bentham, 1989b, p. 4).

These aptitudes articulate different relations between the individual mind and the content of the utilitarian code. The "moral aptitude" refers to the ability to act and think according to the principle of utility. This capacity is fundamental for public officials. The adjective "moral" qualifies the ability of the officials to think like a utilitarian.

... moral aptitude is a negative quality: it is constituted by the absence, in so far as possible, of a certain propensity universal in human nature. This propensity in the breast of each individual is the propensity to sacrifice all other interests to that which at each moment appears to him to be his own preponderant interest: to obtain happiness for himself to whatsoever amount by so doing, he abstracts or withholds it from all other individuals (Bentham, 1989b, p. 13).

The concept of "moral aptitude" explains how one individual considers subjugating his personal interests in order to fulfill the requirement of his office in the public institution. The artificial identification of his interest with his duty proceeds from his ability to sacrifice his personal interests.

$\ldots$ desire is kept down and weakened: the propensity exists but in the character of a
lambent flame by which no combustion is ever produced. This is then what is
possible to be done, done by a form of government such as the desire of rendering
the exercise of it conducive to the greatest happiness of the greatest number is
capable of discovering and recommending for adoption (Bentham, 1989b, p. 13).

The sacrifice of interests also accompanies the conversion of desires and interests so that their transformation leads to the artificial identification with the interest of the greatest number. The "moral aptitude" shows also that one individual does not master perfectly his own interests because they are dynamic, contingent and evolving if necessary. The plasticity of the interests is one dimension on which "moral aptitude" relies. However, the sacrifice of some of his personal interests is not only based on the force of his will but depends on the ability of the functionary to understand and think about the reasons of his sacrifice.

Bentham introduces then the "intellectual aptitude" which is grounded in the faculty of understanding in order to emphasize that the rationale of the sacrifice must be understood. The functionary should respect the sacrifice and not be blindly obedient to the utilitarian code. This "intellectual aptitude" 
requires an "Examinee" (Bentham, 1989b, p. 77)4 who will assess the proper understanding of the functionary. The examination of the "intellectual aptitude" of the functionary relies on his ability to understand and master the appropriate knowledge of his office and the rights and duties attached to it. The knowledge of his duties and his ability to judge correctly are fundamental features of this aptitude. Lastly, the "active aptitude" is defined as the ability of the functionary to be involved in and attached to the realization of the greatest happiness of the greatest number. The public official should not only respect and act in conformity to his duties, and be informed of the normative dimension required by his office in order to act as a utilitarian, because it is also important that the public servant must want to be a utilitarian. This last point gives a full description of what the perfect internalization of the utilitarian code for a public official comprises.

This analysis shows then that Bentham's ethics of politics aims to create an artificial junction between the duty and the interests of the functionary that will at the same time assure the impartiality and justice of public institutions and secure the universal interest from all sacrifices. Bentham thinks that the direct effects of these aptitudes will be concretely demonstrated by the "probity" and "sincerity" of public officials. Bentham focuses on this aspect in two texts in Political Tactics (1788) and The Book of Fallacies (1824). By describing the particular concrete situations, Bentham explains how deputes and public officials shall always speak the truth in the name of the "universal interest" and their own duty and interest to promote the greatest happiness of the greatest number. As such, lying is first and foremost always the mark of a corrupted mind, of the dissimulation of one's own interests.

According to the notions commonly entertained of moral duty under the head of probity, and in particular under the head of that branch of probity which consists in sincerity, whatsoever be the nature and extent of the business in question, private or public, it is not right for a man to argue against his own opinion: when his opinion is so and so, to profess it to be the reverse, and in so doing to bend the whole force of his mind to the purpose of causing others to embrace this opinion thus reverse to his real one (Bentham, 2015, p. 486).

Lying is described as one individual masking his authentic and subjective interests. In the broad sense, lying is bad because one is dissimulating his own

\footnotetext{
4 "Any person who, in the character or situation of a Candidate for the Office, is regarded as being willing that his aptitude with reference to the Office shall be taken into consideration and enquired into, call him an Examinee" (Bentham, 1989b, p. 77).
} 
interests. Applied to public officials, it means that the artificial identification between his interest and his duty is broken and that he does not fulfill his moral duty of sincerity. Masking one's own authentic interests with a lie is masking the non-identification between one public official's interests and his duty which is normatively shaped to respond to the utilitarian end. The dissimulation demonstrates that the aptitudes that the public official should have internalized in order to secure the greatest happiness of the greatest number can fail to guarantee his impartiality. In this case, Bentham considers that the source of a lie made by a public official relies most often in the lack of "intellectual aptitude":

For the performance of it, on the part of the individual corrupted no extraordinary degree of intellectual aptitude - nor so much as the most ordinary human intelligence - is necessary: the degree of intellectual aptitude universally possessed by all domestic animals of an inferior degree is quite sufficient (Bentham, 1989b, p. 21).

The public official who lies is showing less intelligence than when he tells the truth. This idea shows that the selection of candidates and the internalization of the utilitarian code is demanding and that the intellectual aptitude must respond to the rationality that the principle of utility is asking for. Bentham's utilitarian ethics of politics is rational and his liberal optimism interrogates ultimately the degree of rationality that a public official must possess in order to be recognized as fulfilling his duty and doing good work and, correlatively, the degree of authoritarianism the utilitarian code has to have to be able to eliminate lying in politics. If for Bentham, there is no possibility of justifying the necessity of lying in politics, the consequence of this view is that the commitment of the public official to say the truth is then necessary. This idea contradicts the specific political relations and dependencies that exist in politics in general.

Indeed, even during election campaigns, periods of high and intense political debates, the man in charge of the destiny of the interests of the greatest number shall not lie. Beyond all political dependence, beyond all commitment to his own political allies and parties, the words of one public official are the reflection of his interests and, as such, express how his will and his understanding are articulated, i.e. how his state of mind is prepared to respond to the "universal interest”. The principle of the greatest happiness of the greatest number requires a perfect and total incorporation of the utilitarian code, a sacrifice of all personal interests. However, the incorporation of the utilitarian code is not enough and 
the system of control and motivation could be violated. Multiple errors and failures from public officials are always possible and can have many sources. The internal system of control and motivation needs an external support grounded in the role of the critic and free censure articulated by the public and the press. Bentham thinks that the "souls of justice" (Postema, 2014, Ch. 3) lies in publicity and transparency. The more controlled a public official is, the more he wants to respect his duties and act accordance with the "universal interest". The duty of sincerity and truth is then encouraged most notably by the sanction of the public and the discourses of the press.

\subsection{The Censorial and Critical Function of the Liberty of the} Press.

Bentham's writings on the liberty of the press belongs to a particular historical context. These writings are mostly inspired by Spanish politics in the 1820 s and were initiated as a reaction to the prosecution and imprisonment of 'Mora' (an editor), a victim of the policing and censure system exercised by the Cortès. Bentham wrote many texts addressed to the people of Spain. In these letters, he defends the liberty of the press as being not only a fundamental and constitutional right but also a power which has a critical and informative function because it helps secure the maintenance of a good government. Bentham asserts that one can measure the ability of a good government - and of its ability not to lie - by looking at its attempt to limit the liberty of the press.

... to place, on any more advantageous footing, the official reputation of a public functionary, is, to destroy or proportionably to weaken, that liberty, which, under the name of the liberty of the press, operates as a check upon the conduct of the ruling few; and, in that character, constitutes a controlling power, indispensably necessary to the maintenance of good government (Bentham, 2012, pp. 12-13).

The liberty of the press is a symptom of a liberal government where the securities against misrules and the fundamental constitutional rights are secured and do not suffer any limits from the censure of the government. But if a free press is a proof of good government, it is also a condition for freely controlling and criticizing the government and the work of public officials. Yet, the liberty of the press is not a sufficient condition of the true-statement discourses developed by newspapers. Indeed, if in some way, the press is a 'guardian' of the good government, it is not committed to good-faith, evidence-based and enlightened criticism but can tell lies, make calumnies and others non-true statements. As 
such, the critical role of the press leads to a paradox. In order to explain how Bentham solves it, it is necessary to look more closely at the text. Bentham creates several distinctions about the different modalities of lies that can appear in newspapers:

If the imputation is, to a certain degree, particular, - imputing an individual act legally punishable, or at least disreputable, - it constitutes the sort of act expressible by the term defamation: if, to a certain degree vague and general, vituperation. But these sorts of acts are, both of them, commonly treated on the footing of offences: and this too, even where the person who is the subject of the imputation is a private individual, not bearing a part in the exercise of any of those powers (Bentham, 2012, pp. 11-12).

Bentham extends the classical understanding of lies as a false statement with the introduction of a distinction. The category of "defamation" is here a specific category of discourse which is characterized by the precise harm imputed to one individual and is opposed to "vituperation" where the negative effects of the discourse is not precisely defined. Bentham qualifies these acts as "offences" 5. The acts of "defamation" can be defined as a legal offense of the type of "private extra-regarding offences" following the definition of acts that "are detrimental, in the first instance, to assignable persons other than the offender" (Bentham, 1970, p. 188). In this case, a society that expresses the will to define "defamation" as an offence can qualify legally this act as a "private extra-regarding offence" according to the principle of utility. "Defamation" is a border-line case for Bentham because its legal qualification as a legal offence is conditioned by other circumstances that include legal evidence, testimonies and the possibility for the accused to defend himself. In his writings on the liberty of press for Spaniards, Bentham seems to be much more concerned with the fact that the liberty of the press is not a medium for discharging wrong propaganda, but instead, that it should be used in its positive function of controlling the impartiality of public officials.

In the case of the public functionary, for vituperation, how gross so ever, there should be no punishment at all: for defamation, no punishment unless the imputation be false and groundless: nor even then, unless the false assertion, or insinuation, be the result of wilful mendacity, accompanied with the consciousness of its falsity, or else with culpable rashness: namely, with that which is exemplified by the giving credence and currency to an injurious notion, adopted without any, or on palpably insufficient grounds: no separate judicatory: no separate form of procedure, styled penal or criminal, while, in the other case, it is styled civil; and, in the case of

\footnotetext{
5 "Any act may be an offence, which they whom the community are in the habit of obeying shall be pleased to make one: that is, any act which they shall be pleased to prohibit or to punish. But, upon the principle of utility, such acts alone ought to be made offences, as the good of the community requires should be made so" (Bentham, 1970, p. 188).
} 
defamation, in disproof of rashness of assertion, as well as of wilful falsehood, the defendant should be at liberty to make proof of the truth of the imputation; and, for that purpose, to extract evidence from the person who is the subject of it, as he might from any other person at large.

For these notions, speaking in general terms, my reason is - that to place, on any more advantageous footing, the official reputation of a public functionary, is, to destroy or proportionably to weaken, that liberty, which, under the name of the liberty of the press, operates as a check upon the conduct of the ruling few; and, in that character, constitutes a controuling power, indispensably necessary to the maintenance of good government (Bentham, 2012, p. 12-13).

In this text, Bentham asserts that the false statements and the deception generated by these forms of lies weaken the liberty of the press, in the sense that they diminish its ability to control and judge freely the power exercised by the rulers. Indeed, the power to criticize and censure public officials is partly the responsibility of newspapers and is crucial for good government. Bentham's defense of the absolute liberty of the press lists the danger and mischievous political effects that could result from it. This list will never justify the necessity of limiting the freedom of the press. In contrast, limiting the freedom of the press is always the mark of a government that wants to promote the interests of the rulers and sacrifice those of the people.

Bentham also presents a second justification in favor of the liberty of the press that has its root in the analysis of the interests of newspapers and the role of editors and the journalists. Indeed, there should be no boundaries to the liberty of the press because a discourse always expresses an interest and whether the editor of a newspaper is animated by the truth or by the intent to seduce new readers in the public, there cannot be enough wrongs created that could justify the limitation of the liberty of the press. Bentham thinks that public opinion is largely shaped by the interests of the editors who participate in the fabrication of the public opinion. As such, Bentham permits lies because he cares a lot more about the collective effects of lies created by rulers than created by an editor. An editor's view is not separated from the interests of the individuals who comprise the public opinion and, as such, an editor's lies do not lead to the perversion or the total corruption of the society. Bentham never takes the idea seriously that permitting lies could end exacerbating the generalization problem ${ }^{6}$ (what would happen if everyone did the same thing?). There is a gap between forbidding lying

\footnotetext{
${ }^{6}$ On the generalization test in utilitarian thought, see: Lyons (1965, Ch. 1).
} 
for public officials because of the risk of sacrificing the interests of the greatest number and the deceit and lies existing in a society. For Bentham, a society where there is a very significant number of lies, calumnies, false statements, unfaithful discourses produced by newspapers and the public is the mark of, what he calls, a society of "antipathy" (Bentham, 1970, pp. 58, 60-61) and this society is not ruled under the principle of utility.

Antipathy qualifies the relation between conflicting and opposed interests and these lead to reciprocal violence and conflicts. A divided society such as colonies7 represent a society where antipathy nourish the conflicts of interests between individual and public officials. In colonies, the degree of mistrust, disobedience and antipathetic sensibility is so important that the corruption affects the State, the rule of law and poisons all public institutions. Bentham's criticism of colonies is grounded in the observation of the corruption of public officials, governors who exemplify how the abuse of power is always used to promote their own sinister interests against the interests of the people. The corruption of the State and its official in colonies is then a proof of how antipathy forms the basis of the collapse of a political society that runs the risk of falling back into the "natural society"

In this section, I have explained why Bentham takes the moral and political implications of lying in public institutions very seriously. The utilitarian ethics of politics forbids lying in public institutions. The artificial identification of the duty and interest of the functionary with the utilitarian maxim is necessary to secure impartial and just institutions.

\section{Hypocrisy and Hypocrites: Utility against Asceticism.}

Bentham's concern with lying is directly related to the utilitarian principle on which public institutions are based. As a collective utilitarian, his unease regarding lying is associated to the broader subject of the impartiality of public

\footnotetext{
7 "They hate you ... You hate them. For what would you wish to govern a people who hate you? Will they hate you the less for governing them? Are a people the happier for being governed by those they hate? ... For what can you wish to govern a people whom you hate? Is it for the pleasure of making them miserable" (Bentham, 2002, p. 294).

8 "The idea of a state of natural SOCIETY is, as we have said, a negative one. When a number of persons are supposed to be in the habit of conversing with each other, at the same time that they are not in any such habit as mentioned above, they are said to be in a state of natural SOCIETY” (Bentham, 1977, pp. 428-429).
} 
institutions. Hypocrisy seems to be inscribed in the continuity of Bentham's care to provide securities so that the universal interest will not be sacrificed by the rulers. In his study on Political Hypocrisy, David Runciman (2010) devotes a chapter on the philosopher from London. He explains that "the hypocrisy Bentham hates is the hypocrisy of empty words masking real power" or, in other words, "Bentham's overriding conviction is that words that lack meaning are only insisted on by people with something to hide" (2010, pp. 123-124). While Runciman is absolutely right in explaining that Bentham's theory of fictitious entity (Schofield, 2006, Ch. 1) is a central element of his attention to discourses in general, yet, the source of Bentham's opposition and discussion on hypocrisy is first and foremost a debate on the nature of morality, its foundation and the truth of the principle of utility. In this second part, I will explain how much hypocrisy matters for Bentham's defense of the principle of utility.

Bentham's utilitarian thought is associated with the utilitarian motto the greatest happiness of the greatest number. The principle of utility is the foundation of Bentham's entire utilitarian thought and aims to promote the happiness of the overall society:

By the principle of utility is meant that principle which approves or disapproves of every action whatsoever, according to the tendency which it appears to have to augment or diminish the happiness of the party whose interest is in question: or, what is the same thing in other words, to promote or to oppose that happiness. I say of every action whatsoever; and therefore not only of every action of a private individual, but of every measure of government (Bentham, 1970, pp. 11-12).

Morality requires the promotion of pleasure for one individual and for the happiness of the greatest number. Following the research for rationality in morality, the principle of utility, Bentham argues, is the only rational principle that recognizes the "governance of two sovereign masters, pain and pleasure" (Bentham, 1970, p. 11). Grounded in a hedonist psychology, Bentham's moral and legal thought targets the promotion of pleasure and the avoidance of pain for making the society and the world a better place. Bentham's utilitarian ethics articulates the promotion of happiness with morality in every aspect of human's life.

Yet, Bentham's writings show that he developed a great deal of interests in the opposite theories (Bentham, 1970, Ch. 2; 2013; 2014) to the utilitarian ethics namely, the "principle of asceticism" and the "principle of sympathy and 
antipathy". The term "hypocrisy" is mainly used by Bentham to qualify the advocates of the non-utilitarian principles and to value negatively the nature of their error. But why does Bentham reserve the terms "hypocrisy" and "hypocrites" for his adversaries and mostly for the proponents of the principle of asceticism? How does Bentham understand "hypocrisy" and why does he root his understanding of "hypocrisy" in the principle of asceticism? The answers to these questions will, correlatively, enlighten the relation between utility and truth in Bentham's thought.

\subsection{Utility and the Principle of Asceticism.}

Bentham advocates the importance of the principle of asceticism since Introduction to the Principles of Morals and Legislation. Contrary to utilitarian ethics, ascetic ethics "mak[es] war upon pleasure". Ascetic ethics commands not to promote pleasure and happiness; it is composed of "two branches" a negative (which requires the sacrifice of all pleasure) and a positive (which is dedicated to purity and nobility of the sentiment).

By asceticism I understand any system or article of doctrine in and by which endeavours are used to engage men to forego pleasure in any shape for any other cause than the procurement of still greater pleasure in the same or some other shape, or the avoidance of pain to an amount more than equivalent: or to subject themselves [to] pain for any other cause than the avoidance of still greater pain, or the procurement of pleasure to an amount more than equivalent (Bentham, 2013, pp. 10-11).

One individual is guided by the principle of asceticism when his moral conduct shows, generally speaking, the rejection of pleasure and happiness broadly understood as associated to a pretense of acting as a virtuous man. Bentham underlines the direct consequences of this ethical standard, namely its opposition to the principle of utility and its capacity to be "destructive and obstructive of happiness".

Per asceticism, forego pleasure, not to avoid pain, but on its own account: so as to embracing pains. This is utility opposed directly (Bentham, 1983b, p. 30)

The motto of the ascetic is to oppose interests and pleasures to virtue, duty and morality. The sacrifice of all pleasures and interests is the first condition of morality. The ascetic denies the centrality of pain and pleasures and is radically opposed to any hedonist moral psychology. While Bentham does not ignore these oppositions, his analysis goes further and aims to describe precisely what sort of 
morality and ethical principles is involved in the ascetic conduct. Firstly, says Bentham, the ascetic is not against all pleasures but prefers one type of pleasures which is connected to his own character and taste. The virtuous ascetic is looking for the "pleasures of a good name" or "love of reputation". Bentham offers a description of these pleasures:

... the pleasures that accompany the persuasion of a man's being in the acquisition or the possession of the good-will of the world about him; that is, of such members of society as he is likely to have concerns with; and a means of it, either their love or their esteem, or both: and as a fruit of it, of his being in the way to have the benefit of their spontaneous and gratuitous services. These may likewise be called the pleasures of good repute, the pleasures of honour, or the pleasures of the moral sanction (Bentham, 1970, p. 44).

Bentham describes the pleasures which form the basis of the motives of an ascetic conduct. An ascetic individual values the "pleasures of good repute" or "love of reputation" more than any other pleasures. This pleasure is rooted in the way others judge and estimate his conduct to be more demanding and prestigious than other regular conduct. As Bentham says, "The desire of becoming to men in general an object of admiration" (Bentham, 2014, p. 16) shows the social cause that are the basis of this pleasure. An individual is animated by the social prestige associated to one conduct that appears to be exceptional and highly estimate. This analysis unveils the foundation of the virtue by showing that the ascetic is not virtuous for the sake of virtue. Beyond this analysis, Bentham is also interested in the different discourses that try to justify and explain this moral attitude. Bentham identifies the philosopher and the religious man as two traditional types of men who develop ascetic theories. These two types of men are qualified as "moral hypocrites":

... the sort of man in whom the propensity to asceticism has for its efficient cause the desire or love of reputation may be termed the philosophical ascetic: he in whose breast it has for its efficient cause the desire of ingratiating himself with the almighty being, the religious ascetic (Bentham, 2014, p. 16).

The philosopher - such as Socrates - is looking for the social distinction of others citizens and admiration from the young. The religious man - such as Paul - is interested in gaining God's favor. With these two portraits, the "love of reputation" finds different application which, in both cases, result in the deceit of the virtuous conduct. The ascetic is not the authentic virtuous man that he pretends to be. He is very much like a person who creates a virtuous facade to 
attract the favors of others whether in order to create a dependency, a domination or a form of admiration.

Hypocrisy, as a moral category, qualifies then how some individuals pretend to be virtuous, assert the absolute sacrifice of all pleasures while looking for one specific pleasure that Bentham calls the "love of reputation”. But Bentham's interests lies in the "hypocrisy of the hypocrites", i.e. the authors of the double discourse developed by some individuals, groups and authorities who, in the society, promote and seduce the public with this discourse. Bentham's interest in "hypocrisy" is mostly concerned with the ultimate basis of these discourses, i.e. the principle of asceticism as the direct opposite of the principle of utility.

Most of Bentham's analysis on hypocrisy demonstrates the wrongness of the principle of asceticism by describing its consequences (whether moral, political, social) and strengthens the truth of the principle of utility as the best moral principles and a powerful critical principle that reveals the errors of its opposing theories. Bentham detects a hypocritical approach in the discourse developed by most respectable figures such as religious authorities, aesthetic critics and individual authorities.

\begin{abstract}
A man's conduct may be said to be governed by the principle of asceticism in so far as, on any other consideration than that of a more than equivalent good considered as about to accrue either to himself or some other sensitive being or beings from the operation of any other than a supernatural cause, he subjects himself to pain in any shape, considered as pain, or avoids receiving pleasure in any shape considered as pleasure (Bentham, 2014, p. 16).
\end{abstract}

Bentham's definition of the principle of asceticism explains in which sense the principle of asceticism is the strongest opposite of the principle of utility. In short, the terms of the opposition are known and can be listed in a series of distinctions: one claims to "make war against pleasure" while the other claims that pleasure is the only basis possible for morality, one is commanding the purest sentiment and the discipline of the will, the other despises all hierarchy of pleasures in morality, one is promoting the summum bonum, sentiments and model of virtue, the other is grounding morality in objective measure and calculation etc. This series of opposition has an end that Bentham situates in the description of the bad consequences that follow from the principle of asceticism in politics. Bentham believes that politics can end the dispute and demonstrate once and for all the truth and superiority of the principle of utility. 


\subsection{Asceticism and International Politics.}

In her study on hypocrisy, Ruth W. Grant concludes by saying that "liberalism can be criticized, not for being hypocritical, but for refusing to acknowledge the necessity of hypocrisy" (1997, p. 176). She pursues with the following diagnosis:

... liberal theory does not take sufficient account of the distinctive character of political relations, of political passions, and of moral discourse and so underestimates the place of hypocrisy in politics. This is a real and often unrecognized weakness of liberal theory (Grant, 1997, p. 177).

While this assertion remains true overall in the case of Jeremy Bentham, Bentham's view on international politics disproves in part this judgment. Indeed, in this last section, I would like to explain how the international consequences of the tenets of the principle of asceticism is, for Bentham, a key aspect of its moral hypocritical character. The principle of asceticism leads to the most disastrous consequences in world politics and this is not only an argument against the principle of asceticism; for Bentham, it shows the truth of the principle of utility. While Bentham's argument remains unsatisfactory and problematic, the truth of the ethical principle has to be asserted from the tribunal of sensory experience. Bentham considers this to be the last criteria from which a moral theory cannot escape and should be judged.

Bentham identifies several historical and present experiences in international politics where the principle of asceticism appears to have caused devastating effects. Bentham thinks in particular of the causes and reasons for the "holy wars" and others massive human experiences of pains and misery.

It is true, that from the same source from whence, among the religionists, other doctrines and practices, from which misery in abundance was produced in one man by the instrumentality of another: witness the holy wars, and the persecutions for religion. But the passion for producing misery in these cases proceeded upon some special ground: the exercise of it was confied to persons of particular descriptions: they were tormented, not as men, but as heretics and infides. To have inflected the same miseries on their fellow-believers and fellow-sectaries, would have been as blameable in the eyes even of these religionists, as in those of a partisan of the principle of utility (Bentham, 1970, p. 20).

Bentham identifies the causes of war of religion in the principle of asceticism. The same motive and passion, the "love of reputation" is at the source of the war of religion and the war of conquest. The man in power or the sovereign 
is driven by the search for the promotion of the interest of his country; however, the interest of a country promoted by its sovereign is no less his own interest. The sovereign's interest is distorted or confused with the country's interest. The "love of reputation" leads step by step to the sovereign's passionate quest for his own prestige. The primary causes of the war would thus be the close relationship of the passions with the interests of the sovereign. In this description, there is no difference whether it is the Crown of the Pope or the Crown of the King who is the subject to this passion. The "love of reputation" takes a particular form in international politics which has nourished Bentham's analysis, i.e. the very idea of "glory"9.

\begin{abstract}
A king for the sake of gaining the admiration annexed to the name of conqueror (we will suppose power and resentment out of the question) engages his kingdom in a bloody war. His motive, by the multitude (whose sympathy for millions is easily overborne by the pleasure which their imagination finds in gaping at any novelty they observe in the conduct of a single person) is deemed an admirable one. Men of feeling and reflection, who disapprove of the dominion exercised by this motive on this occasion, without always perceiving that it is the same motive which in other instances meets perceiving that it is the same motive which in other instances meets with their approbation, deem it an abominable one; and because the multitude, who are the manufacturers of langage, have not given them a simple name to call it by, they will call it by some such compound name as the love of false glory or false ambition (Bentham, 1970, p. 107).
\end{abstract}

In this text, Bentham describes how "glory" is the passion, the love of reputation that plays a decisive role for the sovereign or the King in international politics. The passions of the sovereign, and the love of reputation precisely, causes war more than ever. The quest for "glory" leads the sovereign to make the most arbitrary and irrational decisions in order to assuage his own desire to be admired. The pleasure of the sovereign leads to the sacrifice of the happiness of the greatest number with the disastrous consequences of war.

However, Bentham differentiates between "true glory" and "false glory". "True glory" is when the interests of the greatest number govern States and when the passionate competition and the competition of the selfish interests of sovereigns is replaced by the wisdom of the principle of utility and respect for international law for international justice. "Glory" is not reduced to the negative passion. In the same way, benevolence can qualify the action of the utilitarian and

\footnotetext{
${ }^{9}$ From Bentham's correspondence, I can say that this development on glory and the cause of wars is related to Bentham's great memories and experience of Fénélon's Telemachus: "Un roi entièrement tourné à la guerre voudrait toujours la faire. Pour étendre sa domination et sa gloire propre il ruinerait ses peuples” (Fénélon, 1965/1717, p. 107; see also de Champs, 2015, p. 26).
} 
a sentiment, "true glory" is a positive sentiment which can be properly recognized when the action of the sovereign conforms to the principle of utility and participates in the promotion of the interest of the greatest number.

In the same way that the ethics of politics forbids lying for public officials, Bentham's utilitarian international politics aims to control the sovereign and the government in such a way that "glory" could qualify the just actions and decisions that respect the rights and duties of each country on the international scene based on the principle of utility. The only principle which, at the international level, cannot be deceitful is the principle of utility. The principle of utility secures the promotion of happiness in the world through a utilitarian code that tries to set up a cosmopolitan theory (Bourcier, 2017) based on a legal system which will guarantee the rights and duties of each country in its relation to pleasure and pain.

\section{Conclusion}

Bentham's utilitarian philosophy recognizes the necessity to fight against hypocrisy and lying though both do not have the same value and raise different questions in Bentham's thought. Bentham's ethics of politics aims to assure that public officials will not sacrifice the greatest happiness of the greatest number but that the rulers will, thanks to the artificial junction between their interest and their duty, act in accordance with the principle of utility. Public officials' lies are then forbidden because they express the separation and opposition between one individual's interests and the duty and function of his office in a public institutions. By exploring Bentham's ethics of politics, the authoritarian dimension of the utilitarian code appears to be clear on two aspects. Firstly, the utilitarian ethics of politics is based on the premise that it is impossible to realize the utilitarian ends without utilitarian public officials. The good of public institutions depend on the conception of the good that public officials hold. Secondly, moral pluralism in public institutions is radically rejected from the understanding of public deontology: all public officials have to be utilitarian.

Contrary to lying, hypocrisy raises a fundamental question for Bentham which is the truth of the principle of utility. Bentham recognizes that hypocrisy qualifies a conduct that pretends to be virtuous and is grounded in a strong will and the sacrifice of pleasures while, on the contrary, it relies on the motive of "love 
of reputation". More fundamentally, the hypocrites are the theorists (whether in philosophy or in religion) who argue for an idea of morality that demands sacrifice of all pleasures, the promotion of social distinction and pure sentiment and a subjective commitment to morality that have no evidence, no objectivity and no rationality. Hypocrites are paradigmatically non-utilitarian theorists and believers in the principle of asceticism. In order to demonstrate the truth of the principle of utility, Bentham develops a negative argumentation that aims to reveal all the wrongs that the principle of asceticism creates while, at the same time, the truth of the principle of utility.

\section{References}

Bentham, J. (1970). Introduction of the Principles of Morals and Legislation. In J. H. Burns \& H. L. A. Hart (Eds.), The Collected Works of Jeremy Bentham. London: The Athlone Press.

Bentham, J. (1977). A Fragment on Government. In J. H. Burns \& H. L. A. Hart (Eds.), The Collected Works of Jeremy Bentham. Oxford: Oxford Clarendon Press.

Bentham, J. (1983a). Deontology together with A Table of the Springs of Action and Article on Utilitarianism. In A. Goldworth (Ed.), The Collected Works of Jeremy Bentham. Oxford: Oxford Clarendon Press.

Bentham, J. (1983b). A Table of the Springs of Action. In A. Goldworth (Ed.), The Collected Works of Jeremy Bentham: Deontology together with A Table of the Springs of Action and Article on Utilitarianism. Oxford: Oxford Clarendon Press.

Bentham, J. (1989a). Constitutional Code (Vol. I). In J. H. Burns \& F. Rosen (Eds.), The Collected Works of Jeremy Bentham. Oxford: Oxford Clarendon Press.

Bentham, J. (1989b). First Preparatory Principles to Constitutional Code. In P. Schofield (Ed.), The Collected Works of Jeremy Bentham. Oxford: Oxford Clarendon Press. 
Bentham, J. (1993). Official Aptitude Maximized, Expense Minimized. In P. Schofield (Ed.). The Collected Works of Jeremy Bentham. Oxford: Oxford Clarendon Press.

Bentham, J. (1995). Securities Against Misrule and Other Constitutional Writings for Tripoli and Greece. In P. Schofield (Ed.), The Collected Works of Jeremy Bentham. Oxford: Oxford Clarendon Press.

Bentham, J. (2002) Right, Representation and the writing on the French Revolution with Nonsense upon Stilts. In P. Schofield, C. Pease-Watkin \& C. Blamires (Eds.), The Collected works of Jeremy Bentham. Oxford: Oxford Clarendon Press.

Bentham, J. (2012). On Liberty of the Press, And Public Discussion and other Legal and Political Writings for Spain and Portugal. In C. Pease-Watkin \& P. Schofield (Eds.), The Collected Works of Jeremy Bentham. Oxford: Oxford Clarendon Press.

Bentham, J. (2013). Not Paul but Jesus, Vol. III, Doctrine. The Bentham Project, UCL. Retrieved from: UCL. http://discovery.ucl.ac.uk/1392179/3/npbj.pdf

Bentham, J. (2014). Of Sexual Irregularities, and Other Writings on Sexual Morality. In P. Schofield, C. Pease-Watkin \& M. Quinn (Eds.), The Collected Works of Jeremy Bentham. Oxford: Oxford Clarendon Press.

Bentham, J. (2015). The Book of Fallacies. In P. Schofield (Ed.), The Collected Works of Jeremy Bentham. Oxford: Oxford Clarendon Press.

Bentham, J. (2016). Preparatory Principles. In P. Schofield \& D. G. Long (Eds.), The Collected Works of Jeremy Bentham. Oxford: Oxford Clarendon Press.

Bourcier, B. (2017). Le plus grand bonheur pour le plus grand nombre de Jeremy Bentham : un utilitarisme cosmopolitique. Revue des philosophies Anglophones, 9: 59-77.

De Champs, E. (2015) Enlightenment and Utility: Bentham in France/Bentham in French. Cambridge: Cambridge University Press. 
Fénelon, F. (1965/1717). Les Aventures de Télémaque (J. Le Brun, Ed.). Paris : Gallimard.

Grant, R. W. (1997). Hypocrisy and Integrity: Machiavelli, Rousseau and the Ethics of Politics. Chicago: University of Chicago Press.

Harrison, R. (1983). Bentham. Routledge: London.

Lyons, L. (1965) Forms and Limits of Utilitarianism Oxford: Oxford Clarendon Press.

Postema. G. J. (2014). The Soul of Justice: Bentham on Publicity, Law, and the Rule of Law. In X. Zhai \& M. Quinn (Eds.), Bentham's Theory of Law and Public Opinion (Chap.3, p.40-63). Cambridge: Cambridge University Press.

Quinn, M. (2012). Which comes first, Bentham's chicken of utility, or his egg of truth?. Journal of Bentham Studies, 14: 1-46.

Runciman, D. (2010). Political Hypocrisy: The Mask of Power, from Hobbes to Orwell and Beyond. Princeton: Princeton University Press.

Schofield, P. (2006). Utility and Democracy: The Political Thought of Jeremy Bentham. Oxford: Oxford University Press.

Schofield, P. (1996). Bentham on the Identification of Interests. Utilitas, 8(2): 223-234.

Schofield, P. (2015). Jeremy Bentham on Utility and Truth. History of European Ideas, 41(8): 1125-1142. 


\title{
THE ROLE OF LYING IN POLITICS O PAPEL DA MENTIRA NA POLÍTICA
}

Kathrin Bouvot*

k.bouvot@gmail.com

\begin{abstract}
The aim of my paper is to discuss the question of whether in the political climate lying is to be seen as a skill, something that an effective politician must do, or whether it is an absolute "no go" realm. Are lying and deception necessary "skills" for achieving success in politics? Is truthfulness in politics a contradiction in itself? Is the political business as such not dirty by nature? When we think about the remarkable number of lies which have been concocted and distributed by politicians in the recent past, the impression that politics and lies indeed go handin-hand emerges, and that the ideal image of politics as a rational instrument for the formulation of generally binding objectives is fraudulent. Should a distinction be made between lies that pursue harmful goals and lies that aim to achieve a good aim? Should politicians be morally justified to lie in order to realise well-meant political objectives?
\end{abstract}

Keywords: lying, deception, success in politics, truthfulness, the problem of dirty hands, moral justification.

Sumário. O objectivo do meu artigo é discutir a questão de saber se no mundo político a mentira é vista como uma competência, como algo que um político eficaz deve fazer, ou antes se é absolutamente interdita. Será que a mentira e o engano são competências necessárias para que haja sucesso em política? Será que a veracidade em política é uma contradição? Será a actividade política enquanto tal suja por natureza ou não? Quando pensamos no número considerável de mentiras geradas e disseminadas por políticos no passado recente, surge a impressão de que a política e a mentira são, de facto, uma dupla inseparável e que a imagem ideal da política como um instrumento racional para a formulação de objectivos gerais vinculativos é fraudulenta. Devemos fazer uma distinção entre mentiras que visam fins nefastos e mentiras que visam fins bons? Devem os políticos ter uma justificação moral para mentir de forma a realizar objectivos políticos bemintencionados?.

\footnotetext{
* Department of Philosophy, University of Vienna.

1 For the translation of my English abstract into Portuguese I would like to sincerely thank Professor Alexandra Maria Lafaia Machado Abranches. I would also like to thank Professor Pedro Miguel Páscoa Santos Martins for his excellent support during the publication process.
} 